rate $=(1-O D d r u g / O D c o n t r o l) \times 100 \%$, The joint utility was evaluated according to the Golden formula $Q=E a+b /$ $(\mathrm{Ea}+\mathrm{Eb}-\mathrm{Ea} \times \mathrm{Eb})[3], \mathrm{Ea}+\mathrm{b}$ was the combined inhibition rate, Ea and Eb were the inhibitory rates of $\mathrm{A}$ and $\mathrm{B}$ drugs.0. $85<\mathrm{Q}<1.15, \mathrm{Q}>1.15, \mathrm{Q}<0.85$ indicates the addition, the synergistic effect, the antagonism of the two drugs. Results and discussion

At the same drug concentration, the survival rate of the cells gradually decreased with the prolongation of the time of action. When the time of action is shorter (less than or equal to 24 hours), the cells have a high survival rate even if the cells are treated with higher drug concentration?so it can not reflect the killing effect of drugs on cells. In this study, 48 $h$ was selected as the time of MTT assay. As traditional Chinese medicine has a complex composition, multi-target, small adverse reaction characteristics, combined with chemotherapy drugs can not only enhance the treatment effect, but also can reduce the adverse reactions. In this study, the ratio of two drugs(TMP: DOX) was 20: 1, 10: 1, 5: 1, 2.5: 1, 12.5: 1 ,each ratio set a different drug concentration value. For the combination of two drugs treatment of Hela cells, we can see that the two drugs only had a additive effect, and was in a dose-dependent manner.Combined treatment of Hep-G2 cells, with the proportion of changes, the two drugs from the additive effect into a synergistic effect, the ratio of 5 : $1,2.5: 1,1.25: 1$, showing a synergistic effect. Combination therapy for the treatment of tumors opened up a new path to improve the previous use of chemotherapy, not only can reduce side effects, but also to strengthen the treatment effect.

\begin{tabular}{|c|c|c|c|c|c|c|}
\hline & $c(\mathrm{mg} / \mathrm{L})$ & & & Effect Of & & Effect Of \\
\hline$\rho(\mathrm{mg} / \mathrm{L})$ & & Inhibition/\% & QHela & $\begin{array}{l}\text { Drugs Combination Inhibition/\% } \\
\text { (Hela) }\end{array}$ & QHep-G2 & $\begin{array}{l}\text { DrugsCombination } \\
\text { (Hep-G2) }\end{array}$ \\
\hline
\end{tabular}

\begin{tabular}{|c|c|c|c|c|c|c|c|c|}
\hline TMP:DOX & TMP & DOX & Hela & & & Hep- & & \\
\hline $20: 1$ & 400 & 20 & 85.4 & 0.993 & + & 80.1 & 1.100 & + \\
\hline & 200 & 10 & 83.2 & 1.006 & + & 69.5 & 1.071 & + \\
\hline & 100 & 5 & 73.6 & 1.001 & + & 63.2 & 1.122 & + \\
\hline & 50 & 2.5 & 52.9 & 1.051 & + & 52.2 & 0.995 & + \\
\hline & 25 & 1.25 & 41.4 & 1.021 & + & 47.5 & 1.083 & + \\
\hline 10:1 & 200 & 20 & 83.9 & 0.988 & + & 79.2 & 1.106 & + \\
\hline & 100 & 10 & 82.4 & 1.013 & + & 68.0 & 1.134 & + \\
\hline & 50 & 5 & 71.7 & 0.990 & + & 62.1 & 1.164 & ++ \\
\hline & 25 & 2.5 & 47.9 & 0.979 & + & 51.8 & 1.023 & + \\
\hline $5: 1$ & 100 & 20 & 82.3 & 0.983 & + & 78.1 & 1.155 & ++ \\
\hline & 50 & 10 & 79.5 & 0.987 & + & 67.6 & 1.182 & ++ \\
\hline & 25 & 5 & 71.4 & 0.996 & + & 59.2 & 1.148 & ++ \\
\hline $2.5: 1$ & 50 & 20 & 81.3 & 0.978 & + & 76.2 & 1.179 & ++ \\
\hline & 25 & 10 & 79.4 & 0.993 & + & 66.7 & 1.200 & ++ \\
\hline $1.25: 1$ & 25 & 20 & 80.4 & 0.973 & + & 76.5 & 1.194 & ++ \\
\hline
\end{tabular}

Table.Inhibitory effects of DOX and TMP on Hela cells and Hep-G2 cells

\title{
References:
}

[1]Wang S, Lei T, Zhang M. The Reversal Effect and Its Mechanisms of Tetramethylpyrazine on Multidrug Resistance in Human Bladder Cancer[J]. PloS one, 2016, 11(7): e0157759.

[2]Cao J, Miao Q, Miao S, et al. Tetramethylpyrazine (TMP) exerts antitumor effects by inducing apoptosis and autophagy in hepatocellular carcinoma[J]. International immunopharmacology, 2015, 26(1): 212-220.

[3]Zhang J, Li J, Shi Z, et al. pH-sensitive polymeric nanoparticles for co-delivery of doxorubicin and curcumin to treat cancer via enhanced pro-apoptotic and anti-angiogenic activities[J]. Acta Biomaterialia, 2017.

UDC 61 DOI 10.22448/AMJ.2017.3.107-108

\section{IMPACT OF LOW TEMPERATURES ON THE EPITELY OF RESPIRATORY WAYS IN RATS OF VARIOUS AGE}

\author{
V.S. Namakonova, N.P. Krasavina, S.S. Tseluyko
}

\section{Amur State Medical Academy, Blagoveshchensk, Russian Federation}

Abstract. With the general cooling of the organism in the epithelium of the cranial and caudal part of the trachea, a greater decrease in the number of basal and especially intermediate elements was noted in older animals compared with young rats, an increase in the number of goblet cells. Most of the intermediate cells are in a state of extrusion. In small bronchi, the number of ciliate cells decreases in old rats, destructive changes increase in them, the number of Clara cells (CC) increases in a state of elimination.

Key words: trachea, bronchi, multi-row epithelium, Clara cells, cell extrusion, low temperatures.

The main role in the implementation of the protective functions of the mucous membrane of the respiratory organs is played by the epithelial lining providing cell proliferation and differentiation. It is known that low temperatures have a negative impact on all airway structures [2]. The loss of respiratory tract epitheliocytes is realized not only by apoptosis, but also by elimination of morphologically viable elements [3]. The reaction of cells and tissues to the effect of low temperatures also depends on the age of the organism, as the level of metabolic processes decreases, which leads to the activation of oxidative stress and the development of a pathological process in the structure of the epithelial layer $[1,4]$.

\section{Materials and methods}

The work was performed on 60 mongrel white rats, aged: 6-7 months (young) and 19-20 months (old). The experimental animals were divided into two main groups (young and old). Each of the groups included 2 subgroups: 1. Intact. 2. Animals that were subjected to general cooling for 14 days for 3 hours daily at a temperature of $-15^{\circ} \mathrm{C}$. The object of the study was the cranial and caudal sections of the mucous membrane of the trachea and the wall of the intra-lobular bronchus (small caliber). From the material obtained, half-thin sections were made which were stained 
with toluidine blue. Photographing was carried out on a microscope "Primo Star" Germany. The calculation of the main types of epithelial cells in the cranial and caudal part of the trachea, as well as the intra-lobular bronchus, was carried out at $100 \mu \mathrm{m}$ length of the epithelial layer.

\section{Results and discussion}

The internal lining of the mucosa of the proximal part of the respiratory tract (trachea) is represented by a multi-row prismatic ciliated epithelium located on the basal membrane. In the thickness of the epithelial layer, both in the cranial and caudal trachea, a process of elimination is observed, which morphologically manifests itself by a change in the site of cell localization, the appearance of a cytoplasmic site on the surface, then the nucleated part and then the final isolation of the cell from the formation. In intact young rats, compared with older animals, epithelial cells are almost twice as likely to be extruded. In old rats ciliated cells are often found in the process of elimination, both without morphological changes, and with signs of partial destruction of the ciliary apparatus and structural rearrangement of the nucleus. With the cooling of the body with the composition of the epithelium, the number of obese and goblet cells increases, often eliminating elements on the apical surface of which there are no cilia. Given the features of the structure of the nucleus there is reason to assume that these are intermediate cells. Which are transitional forms in the development of ciliary and goblet elements. And the number of intermediate cells in older animals is $30 \%$ greater than in young animals. In old rats in the epithelial layer there are zones of hypertrophied ciliate cells, there are degenerate altered elements with signs of dystrophy of the cytoplasm and nucleus. The number of basal cells decreases significantly, most of which have altered nuclei. In the intralobular bronchi, ciliated cells and CS are present in the epithelium, the latter being part of the continuous lining of the bronchioles, which is a continuation of the epithelial stratum of the proximal airways. QA play the role of progenitor cells of the epithelium of bronchioles, they are capable of self-renewal of their own population and differentiation into ciliate cells. In young intact rats in the small bronchus ciliated cells in the main have a regular plan of the structure, between them are located QC, containing a few granules and keeping contact with the basal membrane. Vaccination of the cytoplasm appears in the old rats in the ciliated cells, some cells of the CC lose contact with the basal membrane. In older animals, the process of extrusion of morphologically differentiated epithelium is more common than in young rats [2]. It is known that as the caliber of bronchi decreases and the relative increase in the epithelium of cells with high functional specialization, the proportion of their participation in proliferation increases [3]. It should be borne in mind that with age, there are changes in epithelio-stromal connective tissue interactions in the epithelial lining of the respiratory tract, which leads to the development of involutive processes [2].

Under the action of low temperatures, the number of ciliate cells increases in the composition of the epithelium in young rats, among them, mitotic CM patterns are observed. In old animals, with a general cooling, the number of ciliate cells decreases by almost $20 \%$, many of them have degenerately altered nuclei, a vacuolarized cytoplasm. In older animals, the level of proliferative processes changes more significantly, which can distort the direction of differentiation in the epithelium of the respiratory system.

\section{References:}

1. Men'shchikova, E.B. Oxidative stress. Proxidants and antioxidants / E.B. Menshchikova, V.Z. Lankin, N.K. Zenkov, I.A. Bondar, N.F. Krugovykh, V.A. Trufakin. - M .: The firm "Word", 2006. - 556p..

2. Polyakova, V.S. Structural reorganization of airway and respiratory sections of the lungs under the influence of unfavorable factors of the air environment. V.S. Polyakova, S.M. Zavaleeva, A.A. Stadnikov // Bulletin of the OSU. - 2003. - №1 - P.66-69.

3. Bird, J.E. Supporting cells eliminate dying sensory hair cells to maintain epithelial integrity in the avian inner ear / J.E. Bird, N. Daudet, M.E. Warchol, J.E. Gale // J. Neurosci. - 2010. - V.30, No. 37. - P.12545-12556.

4. Rawlins, E.L. The role of Scgb1a1 + Clara cells in the long-term maintenance and repair of lung airway, but not alveolar, epithelium / E.L. Rawlins, T. Okubo, Y. Xue, D.M. Brass, R.L. Auten, Y. Hasegawa, F. Wang, B.L.M. Hogan // Cell Stem Cell. - 2009. - 4 (6). P. 525-34.

Сведения об авторах: 675000, г. Благовещенск, ул. Горького, 95. ГБОУ ВПО «Амурская ГМА». т. 8-4162319020 .

Целуйко Сергей Семенович, д.м.н., почетный работник высшего профессионального образования, отличник здравоохранения, проректор по науке Амурской государственной медицинской академии E-mail: agma@nm.ru

Красавина Надежда Павловна, д.м.н., профессор кафедры гистологии Амурской ГМА

Намаконова Виктория Сергеевна, аспирант кафедры гистологии Амурской ГMA E-mail: viktoriya0011@mail.ru

Учредитель и издатель журнала ФГБОУ ВО Амурская ГМА Минздрава России. Журнал зарегистрирован Федеральной службой по надзору в сфере связи, информационных технологий и массовых коммуникаций (г. Москва). Свидетельство о регистрации ПИ №ФС 77-55888 от 07.11.2013 г. 675000 г. Амурская область, г. Благовещенск, ул. Горького, 95. ФГБОУ ВО Амурская ГМА Минздрава России, редакция «Амурского медицинского журнала». Факс: 8 (4162) 319-007. Телефон: 8 (4162) 319-020. E-mail: agma@nm.ru, Agma1@mail.ru. С полной версией журнала можно ознакомиться на сайте www.amursma.ru Ответственный редактор: В.П. Кобзарь Подписано к печати 15.09.2017. Отпечатано в издательстве «Деловое Приамурье». 675000, г. Благовещенск, ул. Ленина, 40. Тел. (4162) 77-11-72. Формат 60х84 1/8. Усл. печ. л. 15,4. Тираж 200 экз. Цена свободная. Подписной индекс в объединенном каталоге «Пресса России» - 40757. 